\title{
Long term changes in lung function after surgical treatment of bullous emphysema in smokers and ex-smokers
}

\author{
JA HUGHES, AM MACARTHUR, DCS HUTCHISON, P HUGH-JONES \\ From the Chest and Cardiothoracic Units, King's College Hospital and Medical School, London
}

ABSTRACT Eleven patients who had received surgical treatment for bullous emphysema had regular assessment of lung function for a minimum of four years (mean 8.8, range 4-20 years). For each patient we estimated the annual rate of change in $\mathrm{FEV}_{1}$ and "relaxed" vital capacity (before and after bronchodilator aerosol) and in carbon monoxide transfer factor (TLCO), transfer coefficient (KCO), and arterial carbon dioxide and oxygen tensions $\left(\mathrm{PaCO}_{2}\right.$ and $\left.\mathrm{PaO}_{2}\right)$.

Among the 11 who had undergone operation, all lung function variables declined at a faster rate in those who continued to smoke than in ex-smokers, the difference in rate being significant $(\mathrm{p}<0.05)$ for $\mathrm{FEV}_{1}$ (before bronchodilator), TLco and Kco. In ex-smokers the rate of change in most lung function indices was not significantly different from zero-that is, no change; in smokers all lung function indices except $\mathrm{PaCO}_{2}$ declined at a rate significantly greater than zero. These findings suggest that long term results of surgical treatment for bullous emphysema are likely to be greatly improved if patients abandon smoking.

After surgical treatment of bullous emphysema improvement in lung function has been found in several studies. ${ }^{1-4}$ Beneficial effects on symptoms have also been reported,,$^{5-8}$ though such effects may be poorly correlated with objective changes in lung function. ${ }^{67}$

Improvement in both symptoms and lung function values may be maintained over a long period, ${ }^{26-8}$ though patients who have undergone lobectomy have been reported to fare less well. ${ }^{35}$ We have estimated the annual rate of change of lung function in a group of patients who received surgical treatment for bullous emphysema.

\section{Methods}

Eleven men who had undergone surgical treatment of bullous emphysema have been assessed regularly for a minimum of four years (mean 8.8, range 4-20 years). Details are shown in table 1 . All patients were or had been cigarette smokers. Five patients continued to smoke after their operation, while six

Address for reprint requests: Dr DCS Hutchison, Chest Unit, King's College Hospital Medical School, London SE5 8RX.

Accepted 7 November 1983 abandoned the habit before or immediately after surgery and did not smoke thereafter. There was no significant age difference between smokers and ex-smokers.

Forced expiratory volume in one second $\left(\mathrm{FEV}_{1}\right)$ and vital capacity (VC) before and after inhalation of $200 \mu \mathrm{g}$ salbutamol from an aerosol, transfer factor (TLCo), transfer coefficient (Kco), and arterial oxygen and carbon dioxide tensions $\left(\mathrm{PaO}_{2}\right.$ and $\mathrm{PaCO}_{2}$ ) were measured at each visit as described previously. ${ }^{9}$ Eight patients had lung function assessment before and after surgery.

\section{Results}

$\mathrm{FEV}_{1}, \mathrm{VC}$, and $\mathrm{PaO}_{2}$ improved significantly after operation, whereas TLCo and Kco remained unchanged (table 2). There was no significant difference between the smokers and ex-smokers with respect to postoperative lung function except for $\mathrm{PaCO}_{2}$, which was significantly higher in the exsmokers $(p<0.025)$.

In the smokers all lung function values apart from $\mathrm{PaCO}_{2}$ declined with time and the regression coefficients of all the indices except $\mathrm{PaCO}_{2}$ against time were significantly different from zero. In the ex-smokers only the postbronchodilator $\mathrm{FEV}_{1}$ and 
Table 1 Data on the patients

\begin{tabular}{|c|c|c|c|c|c|c|c|c|c|c|}
\hline \multirow[t]{3}{*}{$\begin{array}{l}\text { Patient } \\
\text { No }\end{array}$} & \multirow{3}{*}{$\begin{array}{l}\text { Age at } \\
\text { operation } \\
(y)\end{array}$} & \multirow{3}{*}{$\begin{array}{l}\text { Age } \\
\text { stopped } \\
\text { smoking } \\
(y)\end{array}$} & \multicolumn{2}{|c|}{$\begin{array}{l}\text { Dyspnoea } \\
\text { grade }\end{array}$} & \multirow{3}{*}{$\begin{array}{l}\text { Chest } \\
\text { radiographic } \\
\text { zone } \\
\text { affected }\end{array}$} & \multirow[t]{3}{*}{$\begin{array}{l}\text { Type of } \\
\text { operation }\end{array}$} & \multirow{3}{*}{$\begin{array}{l}\text { Years } \\
\text { since } \\
\text { operation at } \\
\text { last } \\
\text { assessment }\end{array}$} & \multirow{3}{*}{$\begin{array}{l}\text { No of } \\
\text { post- } \\
\text { operative } \\
\text { visits }\end{array}$} & \multicolumn{2}{|c|}{$\begin{array}{l}\text { Chronic } \\
\text { bronchitis grade }\end{array}$} \\
\hline & & & Before & After & & & & & Before & After \\
\hline & & & \multicolumn{2}{|c|}{ operation } & & & & & \multicolumn{2}{|c|}{ operation } \\
\hline $\begin{array}{l}1 \\
2 \\
3 \\
4 \\
5 \\
6^{*} \\
7 \\
8 \\
9^{*} \\
10 \\
11\end{array}$ & $\begin{array}{l}58 \\
41 \\
69 \\
38 \\
54 \\
45,51 \\
44 \\
44 \\
49,50 \\
63 \\
46\end{array}$ & $\begin{array}{l}(\mathrm{C}) \\
(\mathrm{C}) \\
(\mathrm{C}) \\
(\mathrm{C}) \\
46 \\
44 \\
44 \\
48 \\
45 \\
46\end{array}$ & $\begin{array}{l}3 \\
4 \\
3 \\
3 \\
3 \\
3 \\
\\
3 \\
3 \\
2\end{array}$ & $\begin{array}{l}1 \\
3 \\
2 \\
2 \\
3 \\
2 \\
1 \\
1\end{array}$ & $\begin{array}{l}\text { Upper } \\
\text { Upper } \\
\text { Lower } \\
\text { Upper } \\
\text { Lower } \\
\text { Upper } \\
\text { Upper } \\
\text { Lower } \\
\text { Upper } \\
\text { Upper } \\
\text { Upper }\end{array}$ & $\begin{array}{l}\text { Monaldi } \\
\text { Lobectomy } \\
\text { Lobectomy } \\
\text { Lobectomy } \\
\text { Lobectomy } \\
\text { Lobectomy } \\
\text { Lobectomy } \\
\text { Lobectomy } \\
\text { Lobectomy } \\
\text { Monaldi } \\
\text { Bullae } \\
\text { oversewn }\end{array}$ & $\begin{array}{r}5 \\
20 \\
6 \\
8 \\
12 \\
5 \\
13 \\
6 \\
8 \\
4 \\
9\end{array}$ & $\begin{array}{r}6 \\
12 \\
8 \\
6 \\
8 \\
6 \\
10 \\
8 \\
6 \\
5 \\
6\end{array}$ & $\begin{array}{l}2 \\
2 \\
2 \\
1 \\
0 \\
1 \\
2 \\
2 \\
2 \\
0\end{array}$ & $\begin{array}{l}2 \\
2 \\
2 \\
\\
1 \\
0 \\
1 \\
2\end{array}$ \\
\hline $\begin{array}{l}\text { Mean } \\
\text { SD }\end{array}$ & $\begin{array}{r}50.7 \\
9.6\end{array}$ & & & & & & $\begin{array}{l}8 \cdot 7 \\
4 \cdot 7\end{array}$ & $\begin{array}{l}7 \cdot 4 \\
2 \cdot 1\end{array}$ & & \\
\hline
\end{tabular}

*Lung function data obtained before and after second operation.

C-continues to smoke.

$\mathrm{PaO}_{2}$ declined at a rate significantly different from zero $(p<0.005)$ (table 2$)$.

All lung function variables declined at a faster rate in the smokers than in the ex-smokers, although the differences were significant only for $F E V_{1}$ (before bronchodilator), TLco, and Kco (table 2).

The mean changes in $\mathrm{FEV}_{1}$ and VC (before bronchodilator) were 14 and $19 \mathrm{ml}$ a year in the ex- smokers and 34 and $37 \mathrm{ml}$ a year in the patients who continued to smoke.

\section{Discussion}

Studies on surgically treated patients with emphysema are inevitably biased in the selection of patients, making comparison with other groups

Table 2 Initial postoperative lung function and annual change in smokers and ex-smokers

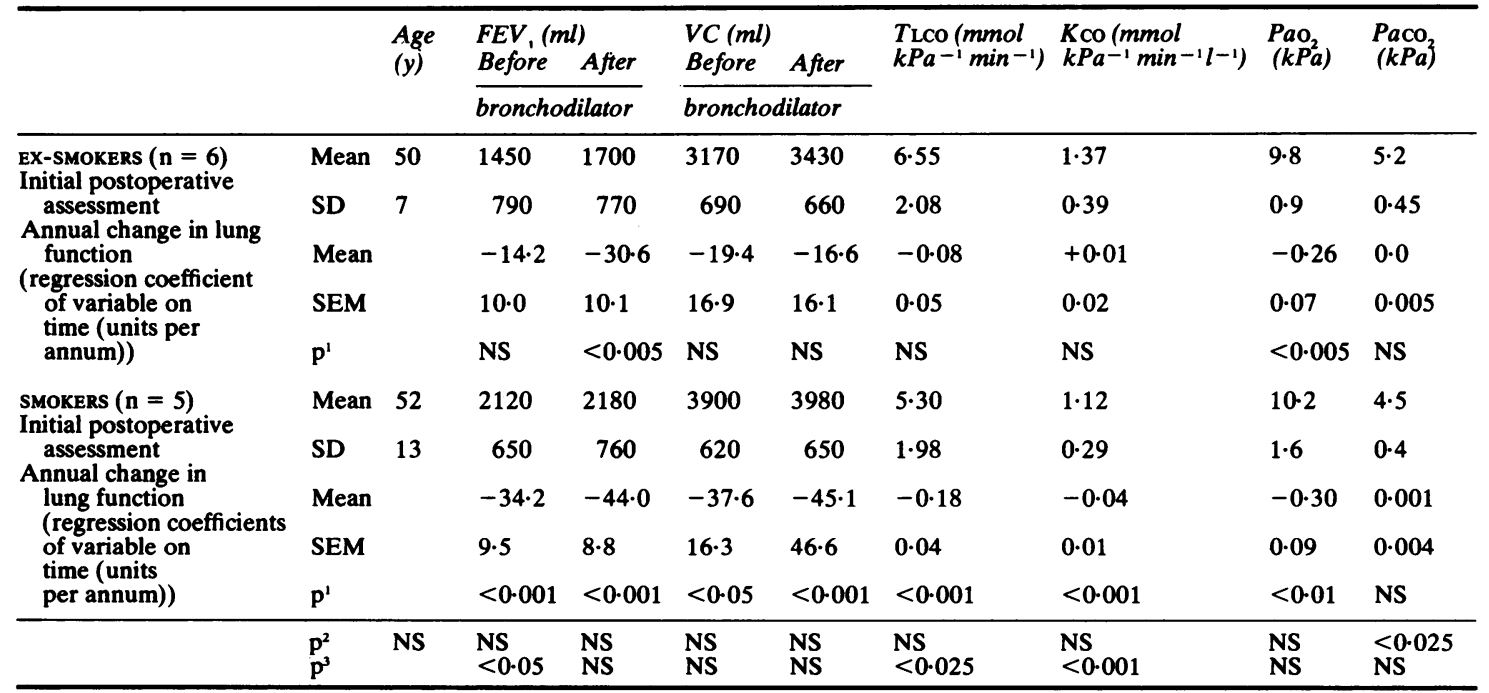

$p^{\prime}$-comparison of mean regression coefficient with zero (that is, no change of lung function variables with time)

$\mathrm{p}^{2}$-comparison of age and initial lung function indices between smokers and ex-smokers

$\mathrm{p}^{3}$-comparison of regression coefficients of ex-smokers and smokers.

NS_not significant; FEV - forced expiratory volume in one second; VC_-vital capacity; TLCo-transfer factor; Kco-transfer coefficient; $\mathrm{PaO}_{2}, \mathrm{PaCO}_{2}$-arterial oxygen and carbon dioxide tensions.

Conversion: SI to traditional units-Blood gas tensions: $1 \mathrm{kPa}=7.5 \mathrm{~mm} \mathrm{Hg}$. 
difficult. We followed only patients who survived for four years, thereby excluding those who died before this. In those who survived for four years lung function variables declined at a faster rate in those who continued to smoke after surgery than in those who abandoned the habit. This result is in keeping with the findings of an earlier study from this department on patients with pulmonary emphysema who did not undergo surgery ${ }^{9}$ and the more favourable postoperative outcome for ex-smokers found by Stone et al. ${ }^{2}$ In ex-smokers the rate of change in most indices was not significantly different from zero-that is, there was no change. Patients who continued to smoke fared less well. All lung function indices except $\mathrm{PaCO}_{2}$ declined at a significant rate.

Several studies ${ }^{1-8}$ have shown both short and long term benefit after surgical treatment of bullous emphysema. Fitzgerald et al, ${ }^{3}$ however, found a reduction in $\mathrm{FEV}_{1}$ of $101 \mathrm{ml}$ a year in 15 patients treated surgically, which is much more than we observed even in our group of smokers. One obvious difference is in the type of operation; most of our patients had had a lobectomy as opposed to bullectomy, though lobectomy is said to give less favourable results. ${ }^{35}$

In a recent study ${ }^{4}$ the rate of decline of $F E V_{1}$ in postoperative patients was $82 \mathrm{ml}$ a year, which is again a higher rate than was found in the present study. Few of the former group, however, continued to smoke, and five of the 11 patients had a bullectomy.

In a group of emphysematous patients not undergoing surgery' the rate of decline in FEV, and FVC was 16 and $15 \mathrm{ml}$ a year in ex-smokers and $53 \mathrm{ml}$ for both in smokers. The decline in lung function was faster in patients with upper lobe emphysema than it was in those with generalised or lower lobe emphysema. ${ }^{10}$ Most patients in this study had had upper lobe bullae before surgery and, interestingly, in the non-operated patients with upper zone emphysema FEV, declined at a mean rate of $46 \mathrm{ml} \mathrm{a}$ year for ex-smokers and $86 \mathrm{ml}$ a year for smokersthough the two groups were not strictly comparable.

Our study was concerned only with patients who survived for four years or more after operation. It is clear that certain patients may live for many years after surgical treatment, even when their initial lung function was poor. Those who continue to smoke appear to deteriorate at a faster rate than those who stop smoking. In some patients the threat of operation or the procedure itself may provide sufficient stimulus for them to abandon the habit.

We owe grateful thanks to the technical staff of the chest unit; to the many physicians, surgeons, and nurses who undertook care of the patients; and to GL Hefford for secretarial help.

\section{References}

${ }^{1}$ Hugh-Jones P, Ritchie BC, Dollery CT. Surgical treatment of emphysema. Br Med J 1966;i:1133-8.

${ }^{2}$ Stone DJ, Schwartz A, Feltman JA. Bullous emphysema: a long-term study of the natural history and the effects of therapy. Am Rev Respir Dis 1960;82:493-507.

${ }^{3}$ Fitzgerald MX, Keelan PJ, Cugell DW, Gaensler EA. Long-term results of surgery for bullous emphysema. $J$ Thorac Cardiovasc Surg 1974;68:566-87.

${ }^{4}$ Pearson MG, Ogilvie C. Surgical treatment of emphysematous bullae: late outcome. Thorax 1983; 38:134-7.

${ }^{5}$ Woo-Ming M, Capel LH, Belcher JR. The results of surgical treatment of large air cysts of the lung. $B r J$ Dis Chest 1963;57:79-85.

- Benfield JR, Cree EM, Pellett JR, Barbee R, Mendenhall JT, Hickey RC. Current approach to the surgical management of emphysema. Arch Surg 1966; 93:59-70.

' Pride NB, Hugh-Jones P, O'Brien EN, Smith LA. Changes in lung function following the surgical treatment of bullous emphysema. $Q \mathrm{~J}$ Med 1970;39:49-69.

${ }^{8}$ Gunstensen J, McCormack RJM. The surgical management of bullous emphysema. J Thorac Cardiovasc Surg 1973;65:920-5.

${ }^{9}$ Hughes JA, Hutchison DCS, Bellamy D, Dowd DE, Ryan KC, Hugh-Jones P. The influence of cigarette smoking and its withdrawal on the annual change of lung function in pulmonary emphysema. $Q \mathrm{~J}$ Med 1982;51:115-24.

${ }^{10}$ Hughes JA, Hutchison DCS, Bellamy D, Dowd DE, Ryan KC, Hugh-Jones P. Annual decline of lung function in pulmonary emphysema: influence of radiological distribution. Thorax 1982;37:32-7. 